\title{
Effect of an $\alpha$-glycosidase inhibitor on experimentally-induced obesity in mice
}

\author{
Y.Le Marchand-Brustel, N. Rochet, T. Grémeaux, I. Marot and E. Van Obberghen \\ INSERM U145, Faculté de Médecine, Nice, France
}

\begin{abstract}
Summary. The effect of prolonged treatment with acarbose, an inhibitor of $\alpha$-glycosidase, has been studied in mice made obese and hyperinsulinaemic by goldthioglucose. After the onset of obesity, one month after goldthioglucose administration, mice were then treated, with or without a $10 \%$ sucrose supplement, for four months with acarbose, added to the diet at $50 \mathrm{mg} / 100 \mathrm{~g}$ food. When mice received a standard diet, acarbose had no effect on body weight, blood glucose or insulin levels. In contrast, in the control obese mice receiving a $10 \%$ sucrose-enriched diet, it decreased the body weight gain, and prevented the rise in glycaemia and insulinaemia. Basal (non insulin-stimulated) glucose uptake, which is decreased in isolated soleus muscle from untreated obese mice,
\end{abstract}

returned to normal values under acarbose treatment. However, muscle insulin resistance was not improved in acarbosetreated obese mice at maximal and submaximal effective concentrations, despite a higher insulin binding in muscles of acarbose-treated obese than in control obese animals. Furthermore, insulin receptor autophosphorylation and tyrosine kinase activity were altered similarly in treated and untreated obese mice compared to lean mice.

Key words: Insulin receptor, tyrosine kinase, goldthioglucose obese mice, insulin resistance, muscle, hyperinsulinaemia, acarbose.
Human and animal obesities are usually associated with insulin resistance, which in vivo is characterized by hyperinsulinaemia and normo- or hyperglycaemia [1,2]. Insulin resistance is also present in vitro, in insulin target tissues such as skeletal muscle [3-6] or adipocytes [7]. In the muscle of obese animals and humans, this resistance results from different abnormalities both at the level of insulin receptor, i.e. decreased receptor number $[3,8]$ and altered receptor tyrosine kinase activity $[8,9]$, and at steps independent from the receptor, such as glucose and amino acid uptake or glycogen synthase activation $[3,4,6,10]$.

Acarbose is a competitive inhibitor of intestinal $\alpha$-glycosidase and thus inhibits starch and sucrose digestion at the level of the small intestine $[11,12]$. The unabsorbed carbohydrates are subsequently degraded by microorganisms in the large bowel. This leads to a decrease in the postprandial rise of blood glucose and, consequently, to a decreased insulin secretion. In genetically obese animals ( $f a / f a$ rats or $d b / d b$ mice), treatment with acarbose was able to prevent hyperglycaemia and to decrease insulin levels. It also diminished the prevalence of diabetic nephropathy in acarbose-treated $d b / d b$ mice [12-15]. Hyperinsulinaemia plays a key role not only in the development of the obese syndrome, since it promotes adipose and liver lipogenesis, but also in the establishment and maintenance of insulin resistance [4]. The use of a model of experimentally-induced obesity makes it possible to perform longi- tudinal studies on the development of obesity and on the effect of treatment before obesity has plateaued. Taking advantage of the potential lowering effect of acarbose on insulinaemia, the present work was undertaken to study the effects of prolonged $\alpha$-glycosidase inhibition on the development of the obese syndrome, and on the state of insulin resistance in skeletal muscle [4].

\section{Materials and methods}

\section{Materials}

Acarbose was a gift of Bayer laboratories (Wüppertal, FRG). Insulin (monocomponent) was purchased from Novo (Copenhagen, Denmark); Triton X-100, N-acetylglucosamine, goldthioglucose, and defatted bovine serum albumin were from Sigma Chemicals (St.Louis, Mo, USA). Wheat germ-agglutinin-agarose was from Miles Scientific. $\left[\gamma^{32}\right.$ P]ATP (triethylammonium salt; aqueous solution, 3,000 Ci/mmol) was from the Radiochemical Centre (Amersham, Bucks, UK). 1- $\left[{ }^{14} \mathrm{C}\right]$-deoxyglucose was from New England $\mathrm{Nu}$ clear (Dreich, FRG) and ${ }^{125} \mathrm{I}$ was from Commissariat à l'énergie atomique (Paris, France). All reagents for sodium dodecyl sulfate (SDS)-polyacrylamide gel electrophoresis (PAGE) were from BioRad Laboratories (Richmond, Calif, USA). Serum from patients B5 or B7 with autoantibodies to insulin receptors was a gift from Dr P. Gorden (Bethesda, Md, USA) and photoreactive insulin ( $\mathbf{B}_{2}$-[2 nitro, 4 azidophenylacetyl $]$ desPhe $\mathbf{B}_{1}$ insulin) was from Dr D. Brandenburg (Aachen, FRG). 

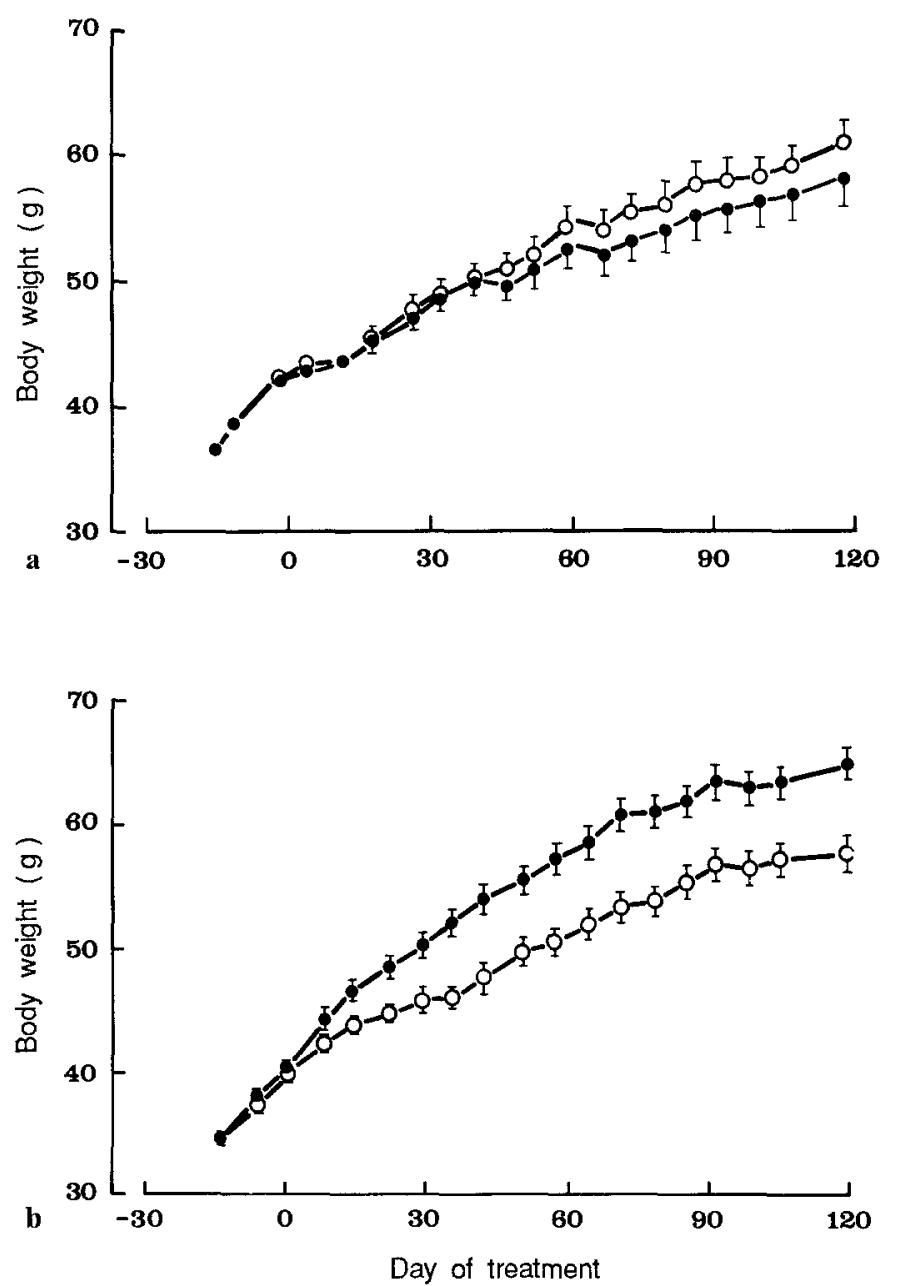

Fig. 1 a and b. Effect of acarbose treatment on the body weight of obese mice. Mice were injected with goldthioglucose at three weeks of age and put, one month later (day 0 ), under acarbose treatment $(50 \mathrm{mg} / 100 \mathrm{~g}$ food) for a period of four months. Two different diets were used: normal diet in the upper panel, diet enriched with $10 \%$ sucrose in the lower panel. Solid symbols: control obese mice; open symbols: acarbose-treated obese mice. Each point is the mean \pm SEM of $30-35$ mice

\section{Animals}

Male Swiss albino mice were fed ad libitum and maintained at $22^{\circ} \mathrm{C}$ on a $12 \mathrm{~h}$ light cycle until the time of death. They were rendered obese by goldthioglucose (GTG) injection at 3 weeks of age [16]. The composition of the laboratory chow (Usine d'Alimentation Rationelle, Villemoisson, Epinay/Orge, France) was as follows (\% weight): protein $22 \%$, lipids $5 \%$, starch $30 \%$, hemicellulose, cellulose and other carbohydrates $25 \%$, salts $6 \%$, water $12 \%$ $(3000 \mathrm{cal} / \mathrm{kg}$ food$)$. Where indicated, food was supplemented with $10 \%$ sucrose. Acarbose (50 mg/100 $\mathrm{g}$ food) was added and thoroughly mixed with the powdered mouse chow before it was reconstituted into pellets.

\section{Experimental protocol}

Mice received goldthioglucose at 3 weeks of age $[3,16]$ and were then weighed twice weekly. Since goldthioglucose treatment does not produce obesity in all injected mice, "preobese" mice were selected at 8 weeks of age on the basis of their body weight gain
( $\geq 0.3 \mathrm{~g} / \mathrm{day}$ ). They were then divided in a control group, which received chow without drug (which will be referred to as "control obese") and a treated group receiving chow containing acarbose ("acarbose-treated obese") for a period of four months. Animals were weighed weekly. In some experiments, age-matched lean mice, which received the sucrose supplemented diet, were also used. At least 30 mice were included in each experimental group and all the experiments were repeated with two-four different groups.

\section{Blood determinations}

Monthly blood samplings $(100 \mu \mathrm{l})$ were performed between 10.00 and 12.00 hours from the retroorbital sinus under diethylether anaesthesia, and plasma stored at $-20^{\circ} \mathrm{C}$. Plasma glucose and immunoreactive insulin were then determined as previously described $[3,16]$.

\section{Deoxyglucose uptake and insulin binding to isolated soleus muscles}

Soleus muscles were isolated and incubated as described previously $[3,5]$. One soleus muscle was preincubated for $60 \mathrm{~min}$ at $37^{\circ} \mathrm{C}$ in $1 \mathrm{ml}$ Krebs-Ringer bicarbonate buffer ( $\mathrm{pH} 7.35$ ), containing $10 \mathrm{mg}$ defatted bovine serum albumin, $2 \mathrm{mmol} / 1$ pyruvate, in the absence or presence of insulin at the concentration indicated in the figures. Deoxyglucose uptake was then measured after a 15 min incubation with 2-deoxy-D- $\left[1-{ }^{14} \mathrm{C}\right]$-glucose $(0.5 \mathrm{mmol} / 1,0.1 \mu \mathrm{Ci} / \mathrm{ml})$. At the end of incubation, muscles were washed, dissolved in $0.3 \mathrm{ml}$ of $1 \mathrm{~mol} / 1 \mathrm{NaOH}$, and an aliquot sample used for determination of ${ }^{14} \mathrm{C}$ content [3]. Insulin binding was measured after a $4 \mathrm{~h}$ incubation at $20^{\circ} \mathrm{C}$ as previously described [3].

\section{Preparation of partially purified insulin receptors and measurement of insulin binding}

Muscles ( $5 \mathrm{~g}$ ) from hindlegs were dissected and used for preparation of partially purified insulin receptors $[9,17,18]$. Aliquot samples $(10 \mu \mathrm{l})$ of receptor preparations were incubated in Hepes $(50 \mathrm{mmol} / \mathrm{l}), \mathrm{NaCl}(150 \mathrm{mmol} / \mathrm{l})$ buffer $\mathrm{pH} 7.6$ containing ${ }^{125} \mathrm{I}$-labelled insulin $\left(10^{-11} \mathrm{~mol} / 1,250 \mathrm{mCi} / \mathrm{mg}\right)$ in the absence or presence

Table 1. Effect of acarbose on body weight gain in obese mice

\begin{tabular}{lccll}
\hline \multirow{2}{*}{\begin{tabular}{l} 
Treatment $\begin{array}{l}\text { duration } \\
\text { (days) }\end{array}$ \\
\cline { 2 - 5 }
\end{tabular}} & \multicolumn{3}{l}{ Change in body weight $(\mathrm{g})$} \\
\cline { 2 - 5 } Control & \multicolumn{3}{l}{ Acarbose-treated } \\
\hline Normal diet & & & & \\
30 & $6.3 \pm 0.7$ & & $5.8 \pm 0.5$ & \\
60 & $10.0 \pm 1.1$ & $3.7 \pm 0.8$ & $11.9 \pm 1.0$ & $6.1 \pm 0.5$ \\
90 & $12.7 \pm 1.4$ & $2.7 \pm 0.6$ & $14.7 \pm 1.2$ & $2.8 \pm 0.5$ \\
120 & $14.4 \pm 1.5$ & $1.7 \pm 0.3$ & $17.7 \pm 1.3$ & $3.0 \pm 0.5$ \\
Food supplemented with $10 \%$ sucrose & & \\
30 & $11.4 \pm 0.7$ & & $6.6 \pm 0.4$ & \\
60 & $18.1 \pm 1.0$ & $6.7 \pm 0.3$ & $12.1 \pm 0.7$ & $5.4 \pm 0.3$ \\
90 & $22.7 \pm 1.1$ & $4.6 \pm 0.3$ & $16.2 \pm 0.9$ & $4.1 \pm 0.3$ \\
120 & $25.7 \pm 1.1$ & $3.0 \pm 0.4$ & $19.3 \pm 1.1$ & $3.1 \pm 0.3$ \\
\hline
\end{tabular}

Mice injected with goldthioglucose were treated without or with acarbose for the number of days indicated. The changes in body weight from the initial weight at the beginning of treatment (overall) and per month are indicated. Values are mean \pm SEM of $30-35$ mice in each group 

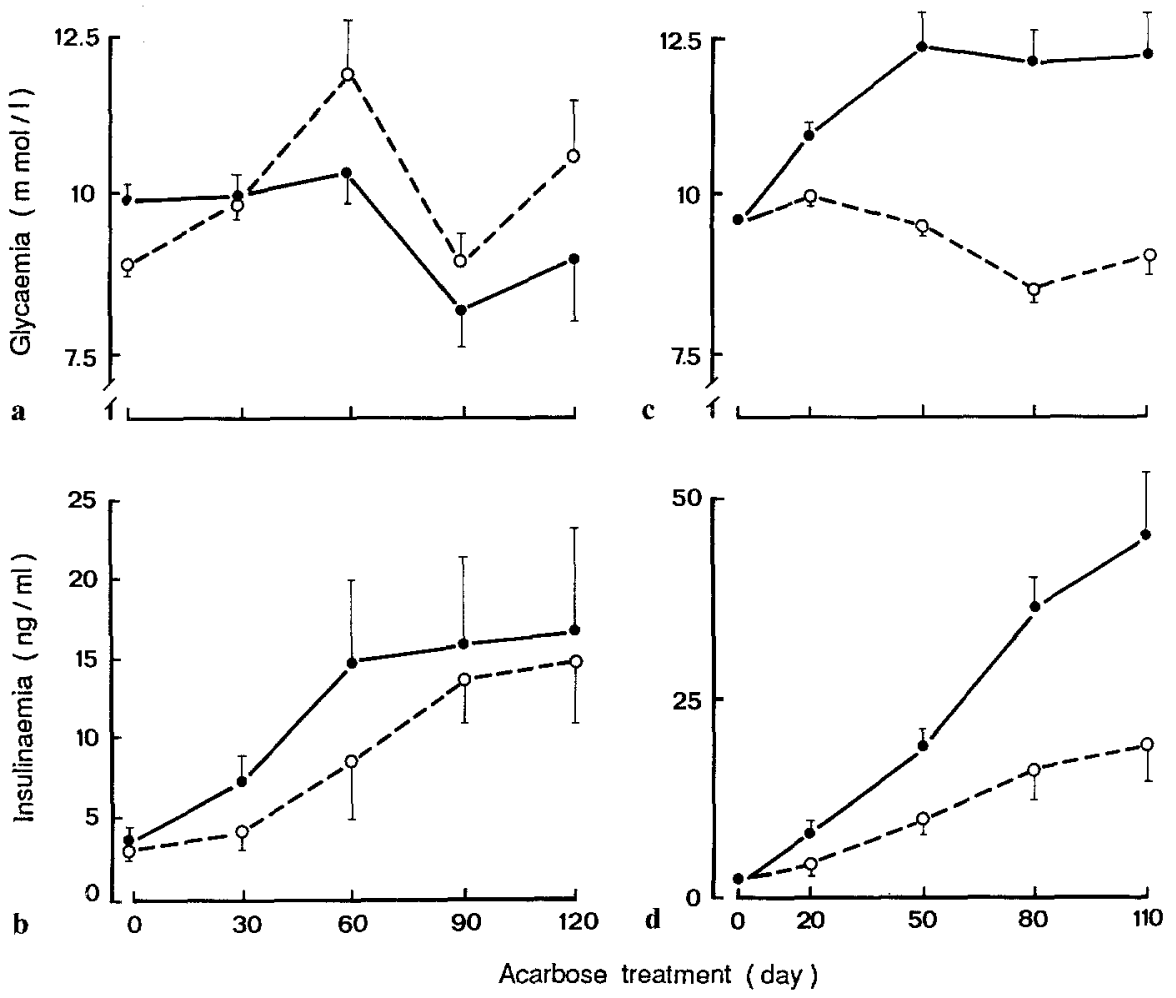

Fig. 2 a-d. Effect of acarbose treatment on glycaemia and insulinaemia in obese mice. Mice, treated as described in the legend to Figure 1, were fed with normal diet (panels $a$ and $b$ ) or with diet enriched with $10 \%$ sucrose (panels $\mathrm{c}$ and $\mathrm{d}$ ). Solid symbols: control obese mice; open symbols: acarbose-treated obese mice. Each point is the mean \pm SEM of $30-35$ values. Differences between control obese and acarbose-treated are significant with $p$ $<0.01$ at days 50,80 , and 110 in panels $c$ and $d$ of unlabelled insulin $\left(10^{-5} \mathrm{~mol} / 1\right)$ in a final volume of $200 \mu \mathrm{l}$. After $2 \mathrm{~h}$ at $20^{\circ} \mathrm{C}$, bound insulin was separated from unbound hormone using polyethylene glycol [19] and the radioactivity of the pellet measured in a gamma spectrometer. To minimize interexperimental variations, the receptor preparations to be compared were always assayed in parallel, wheat germ agglutinin (WGA) -columns were identical, insulin binding was measured in the same assay and phosphorylation was carried out on the same day [20].

\section{Cell-free phosphorylation and immunoprecipitation of partially purified insulin receptors}

To evaluate, on the same gel, both the $\beta$-subunit receptor phosphorylation and insulin binding to the $\alpha$-subunit, the receptor subunits were labelled according to their functions $[9,20]$. Receptors were first labelled on the $\alpha$-subunit using photoreactive insulin. After incubation in the dark for $3 \mathrm{~h}$ at $15^{\circ} \mathrm{C}$ with $5 \mathrm{nmol} /{ }^{125} \mathrm{I}$-labelled $\mathrm{B}_{2^{-}}$ Napa-insulin [21], samples were irradiated for $5 \mathrm{~min}$ at $4^{\circ} \mathrm{C}$ using a mercury lamp. The receptors were then used in a cell-free phosphorylation system $[9,20]$ in order to label the $\beta$-subunit. Finally, the receptors were immunoprecipitated with antibodies against the insulin receptor and analysed by one dimensional SDS/7.5\% PAGE according to Laemmli [22]. The gels were stained, dried, and autoradiographed. The labelled bands were cut and their radioactivity determined for ${ }^{125} \mathrm{I}$ ( $\alpha$-subunit) and ${ }^{32} \mathrm{P}$ radioactivity ( $\beta$-subunit).

\section{Determination of insulin receptor kinase activity using a synthetic substrate}

Partially purified insulin receptor preparations $(30 \mu 1)$ were preincubated for $60 \mathrm{~min}$ at $20^{\circ} \mathrm{C}$ in $140 \mu 1$ Hepes buffer $(50 \mathrm{mmol} / 1, \mathrm{pH} 7.6)$, containing $\mathrm{NaCl}(150 \mathrm{mmol} / \mathrm{l})$, bovine serum albumin $(0.2 \mathrm{mg} / \mathrm{ml})$ and insulin $\left(10^{-11} \mathrm{~mol} / 1\right.$ to $\left.10^{-7} \mathrm{~mol} / \mathrm{l}\right)$. The substrate [poly (glutamate-tyrosine, 4-1), final concentration $0.25 \mathrm{mg} / \mathrm{ml}$ ] was then added for an additional $30 \mathrm{~min}$. Phosphorylation was initiated by adding $20 \mu \mathrm{l}$ of a solution containing $\left[\gamma^{32} \mathrm{P}\right] \mathrm{ATP}(20 \mu \mathrm{mol} / \mathrm{l}, 3,000 \mathrm{cpm} /$ $\mathrm{pmol}), \mathrm{MnCl}_{2}(4 \mathrm{mmol} / \mathrm{l})$ and $\mathrm{MgCl}_{2}(8 \mathrm{mmol} / \mathrm{l})$, final concentra- tions. After $30 \mathrm{~min}$ the reaction was stopped by applying $75 \mu \mathrm{l} \mathrm{sam-}$ ples to filter papers (Whatman ET 31) and soaking the papers in a solution of $10 \%$ trichloracetic acid, and $10 \mathrm{mmol} / \mathrm{l}$ sodium pyrophosphate. After extensive washing, radioactivity of the trichloracetic precipitable material adsorbed on papers was measured using Cerenkov radiation $[9,23]$.

\section{Statistical analysis}

Statistical significance was assessed by Student's $t$-test for unpaired comparisons [24].

\section{Results}

Effect of acarbose treatment on body weight, glycaemia and insulinaemia of obese mice

As shown in Figure 1, upper panel, acarbose treatment had no effect on body weight of goldthioglucose obese mice when normal food was given to the animals. By con-

Table 2. Lack of effect of acarbose on food intake in obese mice

\begin{tabular}{|c|c|c|c|c|}
\hline & \multicolumn{4}{|c|}{ Food intake } \\
\hline & \multicolumn{2}{|l|}{ g/day } & \multicolumn{2}{|l|}{$\mathrm{cal} / \mathrm{day}$} \\
\hline & Control & $\begin{array}{l}\text { Acarbose- } \\
\text { treated }\end{array}$ & Control & $\begin{array}{l}\text { Acarbose- } \\
\text { treated }\end{array}$ \\
\hline Week 1 & $5.9 \pm 0.3$ & $5.9 \pm 0.3$ & $18.9 \pm 1.0$ & $18.9 \pm 1.0$ \\
\hline Week 5 & $5.7 \pm 0.3$ & $5.7 \pm 0.2$ & $18.2 \pm 1.0$ & $18.2 \pm 0.6$ \\
\hline Week 9 & $6.3 \pm 0.3$ & $6.2 \pm 0.2$ & $20.2 \pm 1.0$ & $19.8 \pm 0.6$ \\
\hline
\end{tabular}

Mice injected with goldthioglucose were treated without or with acarbose, food being supplemented with $10 \%$ sucrose. Food intake was measured daily during the first, fifth and ninth weeks of treatment. Values are mean \pm SEM of 15-18 mice 


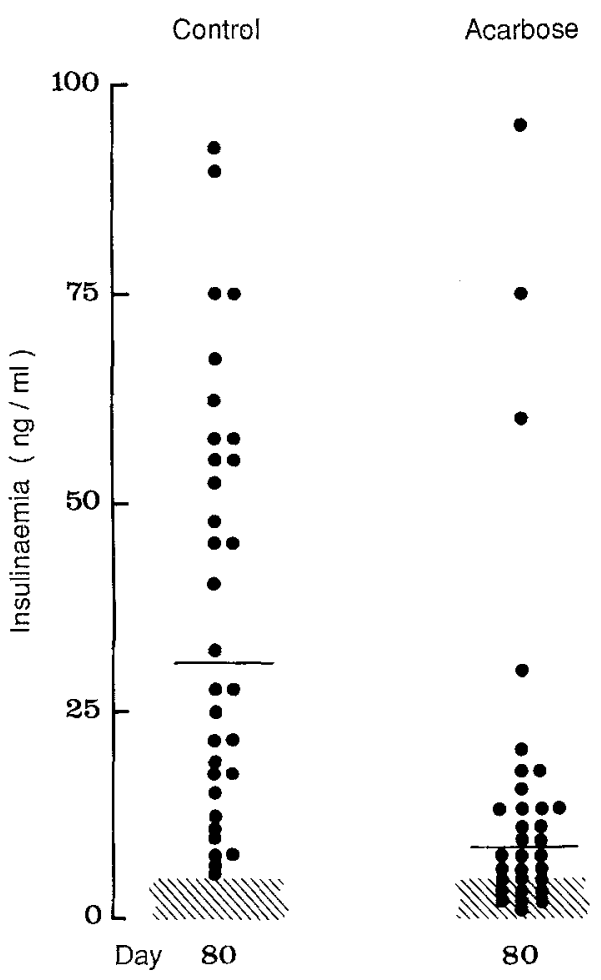

Fig.3. Effect of acarbose treatment on individual insulin levels of obese mice. Obese mice receiving diet enriched with $10 \%$ sucrose were sampled after 80 days of treatment without (control) or with acarbose ( $50 \mathrm{mg} / 100 \mathrm{~g}$ food). Each circle represents an individual insulin value. The bar represents the median value in each group. The hatched area corresponds to the range of insulin levels in normal lean mice

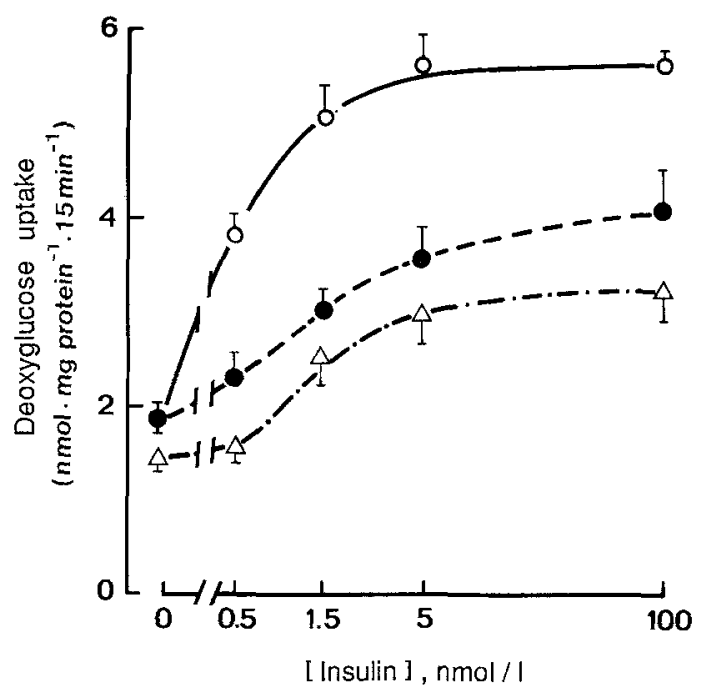

Fig.4. Effect of acarbose treatment on muscle glucose uptake in obese mice. Mice were treated as described in Figure 1 and maintained for four months on a $10 \%$ sucrose-enriched diet. Soleus muscles were isolated from lean $(O-0)$, acarbosetreated $(\bullet-\cdots)$ or non-treated $(\triangle \cdots \cdots, \Delta)$ obese mice. They were incubated for $1 \mathrm{~h}$ at $37^{\circ} \mathrm{C}$ in Krebs Ringer bicarbonate buffer, $2 \mathrm{mmol} / \mathrm{l}$ pyruvate with or without various insulin concentrations as shown on the abscissa. Deoxyglucose uptake was measured at the end of a $15 \mathrm{~min}$ incubation with $1-\left[{ }^{14} \mathrm{C}\right]-$ 2-deoxyglucose. Each point is the mean \pm SEM of $12-16$ muscles. Differences in basal values are statistically significant between lean or acarbose-treated obese and control obese with $p<0.05$ trast, when food was supplemented with $10 \%$ sucrose, acarbose prevented the additional body weight gain due to sucrose (Figure 1, lower panel, Table 1). Acarbose was affecting body weight change mainly during the first month, the body weight gain being similar in control and treated groups during the second, third and fourth months of treatment (Table 1). This reduction in body weight gain was observed without any change in food intake (Table 2).

Blood glucose and insulin determinations were performed monthly in the same groups of mice. When mice received the normal diet, acarbose did not modify glucose levels (Fig. 2 a) but delayed slightly the increase in insulin levels which occurred in control obese mice (Fig. 2 b). However, it was no longer effective after three months of treatment. When food was supplemented with $10 \%$ sucrose, acarbose prevented the rise in blood glucose (Fig. $2 \mathrm{c}$ ) and the huge increase in insulin levels (Fig. $2 \mathrm{~d}$ ) which were observed in control obese mice. Insulin levels were thus similar, at approximately $15 \mathrm{ng} / \mathrm{ml}$, in acarbosetreated obese mice, whether they received the normal food or the diet enriched in sucrose. The insulin lowering effect of acarbose is even more evident when individual insulin levels are presented (Fig. 3). In the control obese group, all animals had insulin levels higher than the normal range (which is indicated by the shaded area), half of the animals having insulin levels higher than $30 \mathrm{ng} / \mathrm{ml}$. By contrast, when animals received acarbose, one third of the animals had insulin levels in the normal range, and $90 \%$ of the animals presented levels lower than $20 \mathrm{ng} / \mathrm{ml}$. It should be noted that a small percentage of obese mice seemed totally resistant to the treatment, insulin levels remaining higher than $25 \mathrm{ng} / \mathrm{ml}$.

\section{Effect of acarbose treatment on glucose uptake and insulin binding in isolated soleus muscle}

Since acarbose was effective only when the food was supplemented with $10 \%$ sucrose, the following series of experiments were performed in mice receiving this diet. An additional group of age-matched lean mice receiving the same diet was studied in parallel. Deoxyglucose uptake was measured as a function of insulin concentration in soleus muscles from mice which had been treated for four months (Fig. 4). In muscles from acarbose-treated obese animals, basal glucose uptake, which was significantly $(p<0.05)$ decreased in untreated obese mice, returned to normal. The insulin effect was similarly altered in untreated and treated obese mice both at submaximal and maximal insulin concentrations.

Insulin binding to soleus muscles has been determined with ${ }^{125}$ I-insulin in the absence (total binding) and in the presence (non-specific-binding) of unlabelled insulin $(1 \mu \mathrm{mol} / \mathrm{l})$ (Table 3 , upper panel). Specific insulin binding was decreased by $35 \%$ and $22 \%$ in muscles of untreated and acarbose-treated obese mice, respectively, compared to lean animals. Similar results were obtained in partially purified insulin receptor preparations (Table 3, lower panel). 


\section{Effect of acarbose treatment on insulin receptor} autophosphorylation and kinase activity

The first step in insulin action following hormone binding to the receptor $\alpha$-subunit is the activation of the $\beta$-subunit tyrosine kinase [25-27]. This enzymatic property was then studied in partially purified preparations of receptors obtained from lean, untreated and acarbose-treated obese mice. Insulin receptors were incubated with ${ }^{125} \mathrm{I}$-photoreactive insulin and subsequently submitted to phosphorylation, before immunoprecipitation with normal serum (Fig. 5, lanes A, C, E) or antireceptor antibodies (Fig.5, lanes B, D, F). The autoradiograms clearly show that less phosphorylation of the insulin receptor $\beta$-subunit occurred both in control obese and acarbose-treated obese mice compared with lean mice. This observation was confirmed by measuring the radioactivity present in the two bands: for an equal amount of insulin binding, $22 \%$ less radioactivity was found in the $\beta$-subunit of control obese or acarbose-treated obese compared to lean animals. The ability of insulin receptors to catalyse the phosphorylation of an exogenous substrate, a copolymer of glutamate and tyrosine residues in a 4:1 ratio, was then investigated (Fig.6). In four different insulin receptor preparations, compared to lean mice preparations where the insulin effect on kinase activity was expressed as $100 \%$, stimulation was found to be $47.2 \pm 5.7 \%$ and $47.7 \pm 2.5 \%$, while insulin binding was $70.7 \pm 4.3 \%$ and $85.3 \pm 3.2 \%$ in control and acarbose-treated obese, respectively (mean \pm SEM).

\section{Discussion}

The results presented in this study show that acarbose treatment partially prevented the development of obesity, hyperglycaemia and hyperinsulinaemia in goldthioglucose obese mice which received a diet enriched with $10 \%$

Table 3. Effect of acarbose on insulin binding to muscles or to partially purified insulin receptors

\begin{tabular}{|c|c|c|c|}
\hline \multirow[t]{2}{*}{ Mouse type } & \multicolumn{3}{|c|}{$\begin{array}{l}\text { Insulin binding to soleus mucles } \\
\text { (\% per mg of protein) }\end{array}$} \\
\hline & Total & Non-specific & Specific \\
\hline Lean & $0.74 \pm 0.09$ & $0.20 \pm 0.01$ & $0.54 \pm 0.09$ \\
\hline Control obese & $0.55 \pm 0.03$ & $0.20 \pm 0.01$ & $0.35 \pm 0.03$ \\
\hline $\begin{array}{l}\text { Acarbose-treated } \\
\text { obese }\end{array}$ & $0.62 \pm 0.04$ & $0.20 \pm 0.01$ & $0.42 \pm 0.04$ \\
\hline Mouse type & \multicolumn{3}{|c|}{$\begin{array}{l}\text { Insulin binding to solubilized receptors } \\
\text { (\% specifically bound per } \mu \mathrm{g} \text { glycoprotein) }\end{array}$} \\
\hline Lean & \multicolumn{3}{|c|}{$7.7 \pm 0.9$} \\
\hline Control obese & \multicolumn{3}{|c|}{$5.2 \pm 0.5$} \\
\hline $\begin{array}{l}\text { Acarbose-treated } \\
\text { obese }\end{array}$ & \multicolumn{3}{|c|}{$6.6 \pm 0.6$} \\
\hline
\end{tabular}

Insulin binding was measured in soleus muscles in the presence of ${ }^{125} \mathrm{I}$-insulin in the absence (total) or in the presence (non-specific) of insulin $\left(10^{-6} \mathrm{~mol} / \mathrm{I}\right)$. Insulin binding to solubilized receptors was measured as described in Materials and methods. Values are the mean \pm SEM of six (soleus muscles) or five (partially purified receptor preparations)

\section{Lean Control Acarbose -}

obese Treated Obese

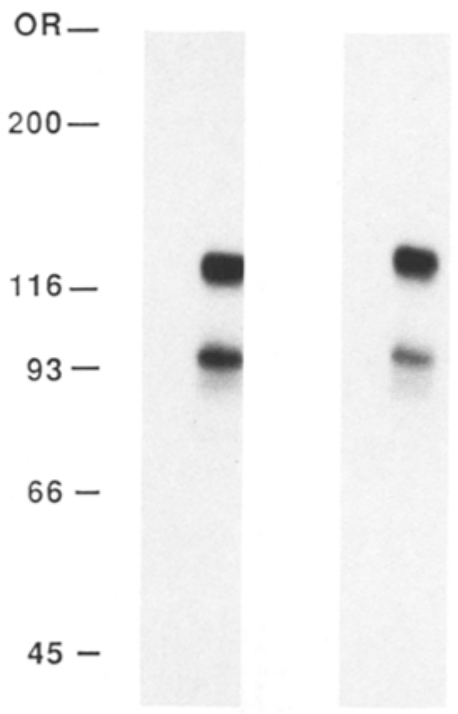

$\operatorname{Mr} \times 10^{-3}$
A B
C D
E $F$

Fig.5. Effect of acarbose treatment on insulin receptor autophosphorylation of obese mice. Muscle insulin receptors were partially purified from lean (lanes A and B), control obese (lanes C and D), and acarbose-treated obese mice (lanes $\mathrm{E}$ and $\mathrm{F}$ ) at the end of four months of treatment, on a $10 \%$ sucrose-enriched diet. Insulin receptors were incubated in the dark for $3 \mathrm{~h}$ at $15^{\circ} \mathrm{C}$ with ${ }^{125} \mathrm{I}$-labelled photoreactive insulin $(10 \mathrm{nmol} / \mathrm{l})$. After ultraviolet irradiation, samples were phosphorylated with $\left.\gamma-{ }^{[32} \mathrm{P}-\mathrm{ATP}\right](15 \mu \mathrm{mol} / \mathrm{l})$ for $15 \mathrm{~min}$ at $20^{\circ} \mathrm{C}$. Samples were immunoprecipitated with normal serum (lanes A, C, E) or serum containing antibodies to the insulin receptor (lanes B, D, F), solubilized and analysed by sodium dodecyl sulfate/polyacrylamide gel electrophoresis as described in Materials and methods. Each band was cut out, radioactivity measured, and the following results were obtained: $\alpha$-subunit, lane B, 11,710 , lane D, 10,046, lane F $8949 \mathrm{cpm} ; \beta$-subunit, lane B, 1899, lane D, 1281, lane F, $1051 \mathrm{cpm}$

sucrose. Similar to the observations made in $d b / d b$ mice [14], food intake was not modified by acarbose. The significantly reduced body weight of the treated-obese animals can therefore be attributed only to the metabolic effects of the drug. Following $\alpha$-glycosidase inhibition, the rate of intestinal carbohydrate absorption is reduced $[11,13]$ and consequently, blood insulin levels are significantly lowered resulting in decreased rates of liver and adipocyte lipogenesis compared to control obese mice. The effect of acarbose in preventing the body weight changes was noticeable only during the first month of treatment. It is possible that the efficacy of the drug was less important after some weeks of treatment since prolonged $\alpha$-glycosidase inhibition induces significant changes in small intestine disaccharidase activity in treated animals [28]. However, this adaptation is not likely to be very large since lowering effects of acarbose treatment on insulin levels persisted even after three or four months. It should be noted that a small proportion of the mice did not display any beneficial effect of acarbose therapy, since they presented very high insulin levels during the whole study, 


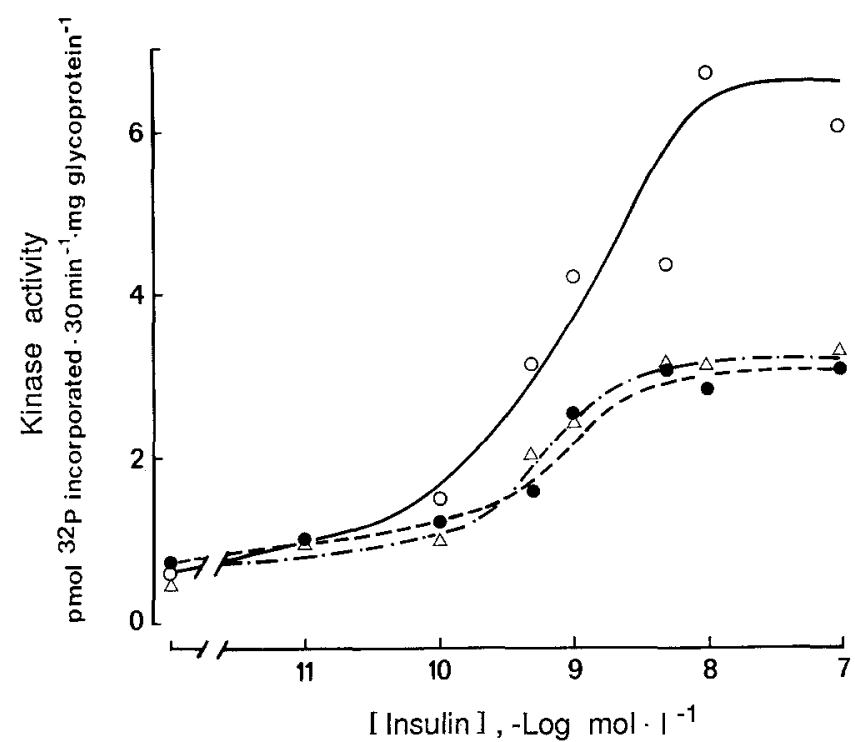

Fig.6. Effect of acarbose treatment on insulin receptor tyrosine kinase activity. Insulin receptors were prepared from muscles of lean $(\mathrm{O}-\mathrm{O})$, control obese $(-\cdots)$ and acarbose-treated $(\Delta-\cdot-\cdot \Delta)$ obese mice as described in the legend to Figure 5. Identical volumes of insulin receptors were preincubated with or without insulin for $1 \mathrm{~h}$ at $20^{\circ} \mathrm{C}$. The copolymer glutamate/tyrosine, $4: 1(0.25 \mathrm{mg} / \mathrm{ml})$ was added and phosphorylation performed for a 30 min period as described in Materials and Methods. The results of one typical experiment (out of four) in which the insulin receptor number was decreased by $30 \%$ in control obese and $15 \%$ in acarbose-treated obese mice are presented

a finding which could be explained by elevated contents of disaccharidases in their intestinal mucosa.

The lowering effect of acarbose on insulin levels was clearly not sufficient to prevent all the alterations in muscle glucose metabolism. Indeed, when glucose uptake was studied in muscles of mice which had been treated for four months, only basal uptake returned to normal values. Decreased basal (non-insulin-stimulated) glucose uptake has been substantiated in different tissues such as skeletal muscle $[3,5,6,18]$ or adipocytes $[7,29]$ of obese animals and humans. This alteration is thought to play a major role in the development of hyperglycaemia and insulin resistance. This diminution results, at least in part, from the reduction in the number of glucose transporters [28, 30]. In adipocytes from fasted and refed rats, the number of glucose transporters strongly correlates with the specific mRNA abundance [31]. It is tempting to hypothesize that insulin resistance is also associated with changes in the level of the glucose transporter mRNA and that acarbose is able to prevent both the decrease in transporter mRNA and in glucose transport activity which occurs in obese animals. Clearly, more studies are needed to clarify the mechanism of its action, but this effect of acarbose therapy probably participates in the prevention of hyperglycaemia in obese mice.

Acarbose treatment also partially prevented the decrease in insulin binding, as measured both in intact soleus muscles or in partially purified insulin receptor preparations, a result which was anticipated from the modifications in insulin levels. Scatchard analysis of the data shows that this reflects changes in insulin receptor number (data not shown). However, the magnitude of this effect was not sufficient to prevent insulin resistance in muscle tissue. Indeed, muscle from acarbose-treated mice was still markedly resistant to insulin both at submaximal and maximal effective concentrations. Furthermore, when autophosphorylation of insulin receptors and their tyrosine kinase activity were studied, the alterations were similar in preparations of control obese and acarbose-treated obese mice. Such a defect in the insulin receptor tyrosine kinase activity has also been reported in skeletal muscles and adipocytes of obese Type 2 (non-insulin-dependent) diabetic patients $[8,9,32,33]$ and probably plays a key role in the insulin resistant state. Although the exact mechanism of the alteration of the kinase activity has not yet been determined [17], it is clear from this study that it does not directly relate to the level of insulin.

In conclusion, this study suggests that acarbose may be of use in reducing the development of obesity and hyperinsulinaemia, in conjunction with high intake of carbohydrates. However, the drug is insufficient to reverse or prevent muscle insulin resistance.

Acknowledgements. We thank Dr. Bischoff, Bayer AG (FRG) for supplying acarbose and for his scientific comments throughout this study, and Bayer Pharma, France, for financial support. We thank Dr. G.W.G.Sharp for his critical reading of the manuscript. We are greatly indebted to Ms. N. Grémeaux for technical assistance, and to Mr. C.Minghelli and Ms. A. Grima for illustrations. The generous gifts of antireceptor antibodies by Dr. P. Gorden (Bethesda, Md, USA) and of photoreactive insulin by Dr. D. Brandenburg (Aachen, FRG) are gratefully acknowledged.

\section{References}

1. Assimacopoulos-Jeannet F, Jeanrenaud B (1976) The hormonal and metabolic basis of experimental obesity. Clin Endocrinol Metab 5:337-365

2. Reaven GM (1988) Role of insulin resistance in human disease. Diabetes 37: 1595-1607

3. Le Marchand-Brustel Y, Jeanrenaud B, Freychet P (1978) Insulin binding and effects in isolated soleus muscle of lean and obese mice. Am J Physiol 234: E348-E358

4. Jeanrenaud B (1979) Insulin and obesity. Diabetologia 17: 133 138

5. Cuendet GS, Loten EG, Jeanrenaud B, Renold AE (1976) Decreased basal, non insulin-stimulated glucose uptake and metabolism by skeletal soleus muscle isolated from obese-hyperglycemic (ob/ob) mice. J Clin Invest 58: 1078-1088

6. Crettaz M, Prentki M, Zaninetti D, Jeanrenaud B (1980) Insulin resistance in soleus muscle from obese Zucker rats. Involvement of several defective sites. Biochem J 186: 525-534

7. Kahn BB, Cushman SW (1985) Subcellular translocation of glucose transporters: role in insulin action and its perturbation in altered metabolic states. Diabetes Metab Rev 1:203-227

8. Caro JF, Sinha MK, Raju SM, Ittoop O, Pories WJ, Flickinger EG, Meelheim D, Dohm GL (1987) Insulin receptor kinase in human skeletal muscle from obese subjects with and without noninsulin dependent diabetes. J Clin Invest 79: 1330-1337

9. Le Marchand-Brustel Y, Grémeaux T, Ballotti R, Van Obberghen $\mathrm{E}$ (1985) Insulin receptor tyrosine kinase is defective in skeletal muscle of insulin-resistant obese mice. Nature 315: 676679

10. Le Marchand-Brustel Y, Freychet P (1982) Alteration of glycogen synthase activation by insulin in soleus muscles of obese mice. FEBS Lett 120: 205-208 
11. Puls W, Keup U, Krause HP, Müller L, Schmidt DD, Thomas G, Truscheit E (1980) Pharmacology of a glucosidase inhibitor. Front Hormone Res 7: 235-247

12. Creutzfeldt W (ed) (1982) Proceedings First International Symposium on acarbose. Effects on carbohydrate and fat metabolism. Excerpta Medica, International Congress Series 594, Amsterdam

13. William-Olsson $\mathrm{T}(1986) \alpha$-Glucosidase inhibition in obesity. Acta Med Scand [Suppl] 706: 1-39

14. Lee SM (1982) The effect of chronic $\alpha$-glycosidase inhibition on diabetic nephropathy in the $\mathrm{db} / \mathrm{db}$ mouse. Diabetes 31:249-254

15. Vasselli JR, Haraczkiewicz E, Maggio CA, Greenwood MRC (1983) Effects of a glucosidase inhibitor (Acarbose, BAY g 5421) on the development of obesity and food motivated behavior in Zucker (fafa) rats. Pharmacol Biochem Behavior 19: 85-95

16. Le Marchand Y, Freychet P, Jeanrenaud B (1978) Longitudinal study on the establishment of insulin resistance in hypothalamic obese mice. Endocrinology 102: 74-85

17. Grémeaux T, Tanti JF, Van Obberghen E, Le Marchand-Brustel $Y(1987)$ Alteration of insulin receptor kinase in obese, insulinresistant mice. Biochimie 69: 387-393

18. Rochet N, Tanti JF, Grémeaux T, Van Obberghen E, Le Marchand-Brustel Y (1988) Effect of a thermogenic agent, BRL 26830A, on insulin receptors in obese mice. Am J Physiol 255: E101-E109

19. Desbuquois B, Aurbach GD (1971) Use of polyethylene glycol to separate free and antibody-bound peptide hormones in radioimmunoassays. J Clin Endocrinol Metab 33: 732-738

20. Le Marchand-Brustel Y, Ballotti R, Van Obberghen E (1988) Insulin receptor kinase activity in states with altered insulin action. In: Kahn CR, Harrison LC (eds) Insulin receptors Part A: methods for the study of structure and function. Liss, New York, pp 163-179

21. Fehlmann M, Le Marchand-Brustel Y, Van Obberghen E, Brandenburg D, Freychet $P$ (1982) Photoaffinity labelling of the insulin receptor in intact rat hepatocytes, mouse soleus muscle, and cultured human lymphocytes. Diabetologia 23: 440-444

22. Laemmli UK (1970) Cleavage of structural proteins during the assembly of the head of bacteriophage T4. Nature 227: 680-685

23. Braun S, Raymond WE, Racker E (1984) Synthetic tyrosine polymers as substrates and inhibitors of tyrosine-specific protein kinases. J Biol Chem 259: 2051-2054
24. Snedecor GW, Cochran WG (1967) Statistical methods, $6^{\text {th }}$ edn. Iowa State University Press, Ames

25. Gammeltoft S, Van Obberghen E (1986) Protein kinase activity of the insulin receptor. Biochem J 235: 1-11

26. Rosen OM (1987) After insulin binds. Science 237: 1452-1458

27. Kahn CR, White MF (1988) The insulin receptor and the molecular mechanism of insulin action. J Clin Invest 82:1151-1156

28. Lee SM, Bustamante SA, Koldovsky O (1983) The effect of alpha-glucosidase inhibition of intestinal disaccharidase activity in normal and diabetic mice. Metabolism 32: 793-799

29. Garvey WT, Huecksteadt TP, Matthei S, Olefsky JM (1988) Role of glucose transporters in the cellular insulin resistance of type II non-insulin-dependent diabetes mellitus. J Clin Invest 81: 1528 1536

30. Zaninetti D, Greco-Perotto R, Assimacopoulos-Jeannet F, Jeanrenaud B (1989) Dysregulation of glucose transport and transporters in perfused hearts of genetically obese (fa/fa) rats. Diabetologia 32: 56-60

31. Kahn BB, Cushman SW, Flier JS (1989) Regulation of glucose transporter-specific mRNA levels in rat adipose cells with fasting and refeeding. Implications for in vivo control of glucose transporter number. J Clin Invest 83: 199-204

32. Freidenbérg GR, Henry RR, Klein HH, Reichart DR, Olefsky JM (1987) Decreased kinase activity of insulin receptors from adipocytes of non-insulin-dependent diabetic subjects. J Clin Invest 79:240-250

33. Arner P, Pollare T, Lithell H, Livingston JN (1987) Defective insulin receptor tyrosine kinase in human skeletal muscle in obesity and Type 2 (non-insulin-dependent) diabetes mellitus. Diabetologia 30: 437-440

Received: 18 May 1989

and in revised form: 25 September 1989

Dr. Y.Le Marchand-Brustel

INSERM U145

Faculté de Médecine

Avenue de Valombrose

F-06034 Nice Cédex

France 